\title{
POEZIA VISULUI REAL
}

\author{
Deaconu ( Ticărău) Iulia-Maria \\ Universitatea „Lucian Blaga” din Sibiu
}

\begin{abstract}
This article aims to review the anthology One Hundred and One Poems that includes a collection of poems and critical quotes selected by Alina Bako, who not only provides an overview of the lyrical universe created by Leonid Dimov, but also the critical tools needed for the specialized or non-specialized reader in order to step into the essence of Dimov's creation. Thereby, the researcher contributes to the revival of the work of a poet who is still actual and valuable.
\end{abstract}

Keywords: review, One Hundred and One Poems, Leonid Dimov, Alina Bako;

Antologia $O$ sută și una de poezii conține o selecție atentă și echilibrată a operei lui Leonid Dimov. Titlul și alegerea de a selecționa acest număr de poezii ne duce cu gândul la poveștile din O mie și una de nopți, cu precizarea că în poemele lui Leonid Dimov regăsim imagini onirice inedite, povești-imagini izvorâte din cel mai lucid vis, un vis real „diferit de cel romantic sau suprarealist și colportând viziuni fantasmagorice, cu obiecte însuflețite și personaje hibride”. ${ }^{1}$

Studiul introductiv al antologiei, selecția de referințe critice și implicit a poeziilor din

\footnotetext{
${ }^{1}$ Alina Bako, în studiul introductiv al antologiei O mie și una de poezii, București, Editura Academiei Române, 2019, p. 5.
} 
volumele Versuri ( 1966), Șapte poeme (1968), Pe malul Stixului (1968), Carte de vise ( 1969), Semne cerești (1970), Eleusis (1970), Deschideri (1972), Amintiri (1973), La capăt (1974), Litanii pentru Horia ( 1975), Dialectica vârstelor (1974), Tinerețe fără bătrânețe ( După Petre Ispirescu și nu prea) ( 1978), Spectacol ( 1979) și Veșnica reîntoarcere ( 1982) sunt făcute de Alina Bako cu scopul de a scoate în relief particularitățile liricii dimoviene, fondator al onirismului de grad secund, cum îl numește cercetătoarea, deoarece vorbim despre un vis în realitate, o realitate a ostentației, a supraîncărcării, a detaliului, a înseși vieții văzute ca un vis. Trăsăturile baroce ale poemelor dimoviene sunt enumerate amănunțit și punctual de Matei Călinescu în volumul Fragmentarium: , o mare bogăție verbală, dublată de stricta stăpânire a resurselor de ambiguitate a limbajului; o vădită propensiune spre hiperbolă sub a cărei cupolă magică se desfășoară jocul scânteilor, paradoxal, al celor mai imprevizibile metamorfoze; un cult, totodată, pentru miniatural, pentru preciziile infinitezimale, pentru detaliul rar, prețios; în sfâșit, și mai presus de celelalte, tendința de a oferi ontologicului sensuri estetice."2

Bogăţia verbală și ambiguitatea din poemele dimoviene sunt evidente în versuri precum: ,, Adună-ți lucrul și vin în barcă,/ Vom sta la umbră de mânătarcă, / E plasa dată cu cert gudron/, Pescari de spijă fac cor afon/ Și scuipă-n soarele de dimineață/ De pe marele cargou ivit din ceață,/ Transportând o Africă din lemn sculptată” ( Vis amalgamat). Imaginile eterogene din aceste versuri, creează o realitate sinestezică, îmbinând vizualul cu olfactivul și auditivul cacafonic al pescarilor care alcătuiesc un cor afon care scuipă și creează ambiguitate prin analogia dintre muzicalitatea unui cor și comportamentul rudimenatar al acestor oameni care produc o muzică proprie, familiară doar lor.

Un amestec de animal: țepi, urechi de elefant, magmă și apă este eul poetic, o formă hibridă dintre om, animal și natură, care erupe din propriul corp pentru a forma un singur element și creează una dintre metamorfozele inedite pe care le răgăsim în versurile lui Leonid Dimov: „Aveam trei țepi înspăimântători/ drept în creștetul capului pleșuv, / Îmi ieșea fum din nări ca din Vezuv,/ Mi se bălăbăneau urechile de elefant -/ Și creșteam necontenit, gol acuma și gigant, / Îmi plesnise un ochi nencăput sub pleoapă/ Și curgea din el un fel de apă/ Parfumată și străvezie.” ( din volumul Eleusis). Alina Bako în studiul introductiv al antologiei constată că unul dintre elementele de inovaţie și originalitate care transpare din poemele lui Dimov este corporalitatea, mai exact corpul văzut precum un obiect ce ,, preia din substanța lumii exterioare, din zona

\footnotetext{
${ }^{2}$ Matei Călinesu, apud op. cit., p. 250.
} 
mineralului sau a substanțelor inerte" ${ }^{3}$. Totodată, aceasta întărește această afirmație prin identificarea la nivel poetic al unei corporealități, ,,adică o transpunere a corpului într-o realitate, de data aceasta onirică." 4 Versurile menționate anterior nu fac decât să întărească această afirmație, corpul nu mai este o instanţă individuală, definitorie, o componentă infimă a realității, ci devine el însuși o realitate, alcătuită din elemente disparate, aparent imposibil de grupat, o realitate onirică, dar nu mai puțin adevărată, iar Leonid Dimov creează această corporealitate prin utilizarea hiperbolei, prin hiperbolizarea și metamorfozarea propriului corp: „şi creșteam necontenit, gol acuma și gigant".

Un alt exemplu de metamorfoză, omul care are solzi pe spinare, o coadă în formă de trifoi, copite în loc de degete la picioare, cu o ureche bleagă și una dreaptă ne duce cu gândul la o imagine a unui corp hidos născută dintr-o fantezie debordantă, ancorată în elemente ale realităţii regnului animal care se contopesc pentru a da naștere unei ființe fabuloase, dar care este alcătuită din elemente concrete: „Că mi-au crescut solzi cocliți pe spinare,/ Că am o coadă trilobată și copite la picioare,/.../Că una din urechi e dreaptă, iar cealaltă, bleagă -" ( din volumul Eleusis). De această dată, această imagine metamorfozată este văzută de o altă persoană, iubita, care îl vede în acest fel și îi atribuie culpa pentru această transformare: ,poftim o garoafă/ S-o dați iubitei aceleia dulci, de pe strapontină,/ Să nu mai spună că eu sunt de vină”. Ioan Bogdan Lefter ( în volumul 5 poeți: Naum, Dimov, Ivănescu ) remarcă faptul că onirismul lui Leonid Dimov este alcătuit din descrierea amănunțită a realității, prezentată prin prisma dualității vizibil-invizibil, obișnuit-neobișnuit: „Onirismul lui Leonid Dimov este, de fapt, o fascinantă imagine a lumii, fantezistă, da, dar realistă în fond, o descripție copleșitoare a vieții, cu amestecul ei de banal și fabulos, de profan și de mitic, de concret și abstract."

Folosirea metamorfozei este un mijloc prin care poetul creează imagini onirice lucide, părți componente ale unei lumi singulare, unde nu mai există bariere între ceea ce se vede cu ochiul liber, ceea ce este comun și cotidian și ceea ce ține de partea metafizică a existenței umane, o lumeamalgam în care singurul regret este cel al nostalgiei după copilărie: , Copilărie desculță ducem acolo,/ Cu bidoane de gaz și de măsline Volo,/ Și câtă durere pe ziduri se lasă/ La prânz, când din casă ne cheamă la masă." ( Vis de mahala)

\footnotetext{
${ }^{3}$ Alina Bako, op.cit. p.9.

4 Ibid., p.9.

${ }^{5}$ Ion Bogdan Lefter, apud op.cit., pag 251.
} 
O altă modalitate de creație pe care o folosește Leonid Dimov este aceea de a construi o realitate din locuri existente, cunoscute, cărora le dă nume imaginare care nasc, astfel, o realitate nouă, virgină, clădită pe cea veche, dar actualizată tocmai prin redenumirea componentele spațiale ale acesteia. Iată cum portul vechi al unui fluviu al cărui nume 1-a uitat este reancorat în realitatea nou construită: „Hai să-i dăm un nume ciudat:/ Aruarodiz,/ Adică: apă țintuită de guvizi/ Și, precum marii descoperitori din vechime,/ Să le punem tuturor numele prime./ Dealului cu legănători, de colo, / Să-i spunem, de pildă, Ubadololo/ ..../ Ne vom îndrepta apoi pe Vilovali,/ Calea fluturilor sinilii,/ Vom ajunge la Maru be Morb:/ Monumentul jumătăților de corp,/ După care vom sui pe Libelolite:/ Colina rozelor etern ofilite,/ Vom dansa pe Balgorubal:/ Esplanada melcilor de cristal/ Până pe treptele lui Ilulelite:/ Palatul jocurilor cu bile.” ( XXXIII ). Folosirea unor nume inventate precum Aruarodiz, Ubadololo, Maru be Morb, Libelolite, Balgorubal, Ilulelite nu este decât un mod de re-crea realitatea și de a o descompune în microspații care sunt compuse dintr-un singur element, fiecare element construind o lume aparte.

Ermetismul, ca trăsătură definitorie a universului liric dimovian, este evidențiat prin îmbinarea abracadabrantă a cuvintelor, care face ca mesajul poeziei să fie foarte deficil de descifrat pentru cititor: „Dac-aș putea să sfredelesc/ Livid cuvântul verde/ Și-n nesfârșitul puț lumesc/ Să văd lumina cum se pierde/ Cum se rotesc în jurul lor/ Știrbite litere, degeaba,/ Cum un vulpoi multicolor/ Le mai oprește, strâmb, cu laba" ( Istorii cu domestic iz, Prolog ). Cuvântul care nu se mai află la început, la baza creației, ci „,drept în mijloc/ E Cuvântul: fără îndoială ” (Bun rămas) nu mai creează lumea, funcția esențială a acestuia fiind căutarea sensurilor ascunse, fărâmițarea acestuia, pătrunderea în interiorul literelor din care este format și proslăvirea imaginației ca unică sursă prin care realitatea poate fi cunoscută.

În volumul Carte de vise, ciclul „Poeme de veghe”, Leonid Dimov folosește termeni specifici sferei religioase pe care îi integrează în cotidian printr-o împreunare care pare atât de firească, încât sacrul și profanul devin ingredintele indispensabile ale unei lumi transparente, în care credința devine concretă. Biserică, pronaos, clopotniţi, bazilica, altar, vecernii, sărbătoare, spovedanie, rai, naos, sfânt, Dumnezeu sunt părți componente ale unui univers care prinde viață din picturile religioase și devin materiale: „, Curgea o umbră de rai vopsit./ Clătina din clopotniţi marele naos scorojit/ Și chiar lângă lucarnă, violet pe jumătate,/ Sfântul Ieronim cu buzele țuguiate./ Tremurau de frig și de-ntuneric mut/ Plutind încet spre lumenul șţiut.”

Cromatica joacă, de asemenea, un rol important în universul visului real, prin construirea 
unor imagini surprinzătoare. Acestea se găsesc fie singular în multe dintre poemele dimoviene: „labă albastră”, „radă cafenie pe verde închis”, „,sunet azuriu”, ,galbenul voiaj”, „mov Eden”, ,cai vineții”, dar și concentrate într-o singură strofă : „Casele rombice; verzi malachite, / Prispele: lapisuri lazulii,/ Grindine roșii, încremenite/ Plase veghează-n uliți pustii” ( din volumul Eleusis).

Ultimul poem selectat de Alina Bako, „Liftul”, face parte din volumul Veșnica reîntoarcere și este, din punctul meu de vedere, o alegere extrem de inspirată pentru a încheia această antologie. Așteptându-și iubita, eul poetic, îi adresează retoric acesteia niște sfaturi pentru a ajunge cât mai rapid la lift: „Gândește-te numai la noi, nu privi în spate,/ Fă-ți drum cu coatele, nu te abate, / Ocolește țigăncile cu flori, tonetele pline de praf, / Nu intra la bar, nici la cinematograf". Apoi continuă și o îndeamnă să nu se oprească : ,, De ce te-ai oprit? Ia-o înainte!/ Ce ți-a mai trecut prin minte?/ Uite, negustoreasa și-a luat năframă nouă/ Și te îmbie cu smântână și ouă/ De vânzare./ Strecoară-te printre produsele alimentare/ Și vino mai iute că vine liftul. Și n-așteaptă.” Liftul care nu așteaptă este un simbol al unei realități ireversibile: fugit irreparabile tempus, iar conștientizarea acestui adevăr imuabil nu îl face pe creator să se descurajeze, ci dimpotrivă este un imbold perpetuu care-1 face pe acesta să nu se oprească din a crea, din a naște realități prin vis: „Sunt aici: rozalb ca-ntotdeauna și încrezător/ În pofida vârstei lângă ascensor.”

Andrei Terian semnalează următoarele trăsături ale liricii lui Leonid Dimov, trăsături care sunt definitorii și care sintetizează întreaga sa creație poetică: „Dacă numeroși poeți sunt obsedați de plăsmuirea unei lumi din materialul vaporos al cuvintelor, la Dimov dificultatea nu e să dea concretețe ficțiunilor, ci să le controleze mai departe, odată ce acestea au luat ființă. E ca și cum creațiunea se răzbună pe creator [...] Am putea aproxima acest proces prin cunoscuta gravură a lui Escher, în care două mâini se desenează una pe cealalată"6 . Întreaga opera a lui Leonid Dimov are la bază visul ca realitate, o realitate în care opera își concepe creatorul, a creatorului care se identifică cu propria creație.

Prin selecția poemelor și a citatelor critice din antologia $O$ sută și una de poezii, Alina Bako nu face doar o panoramare a universului liric creat de Leonid Dimov, care oglindește „un filon de gândire autentică ce caracterizează momentul oniric al poeziei românești din secolul al XX-lea” 7 , ci îi oferă și instrumentele critice necesare cititorului specializat sau nespecializat pentru a pătrunde

\footnotetext{
${ }^{6}$ Andrei Terian, apud op.cit., p.252

${ }^{7}$ Alina Bako, op.cit. pag 11
} 
în esența creației. Procedând astfel, cercetătoarea contribuie la revirimentul operei unui poet încă actual și valoros.

\section{Bibliografie}

Leonid Dimov, O sută și una de poezii, București, Editura Academiei Române, 2019, antologie, studiu introductiv și selecția referințelor critice de Alina Bako. 